\title{
A Comparison between Dedicated and Flexible Manufacturing Systems: Optimization and Sensitivity Analysis
}

\author{
Abdul Salam Khan', Khawer Naeem², Raza Ullah Khan ${ }^{3}$ \\ RECEIVED ON 29.05.2019, ACCEPTED ON 23.06.2019
}

\begin{abstract}
An abrupt change requires a robust and flexible response from a manufacturing system. Dedicated Manufacturing System (DMS) has been a long practiced taxonomy for mass production and minimum varieties. In contrast, Flexible Manufacturing System (FMS) has been introduced for responding to quantity as well as variety issues. This study considers both production taxonomics by using a multi objective model of cost and time. An Integer Linear Programming (ILP) formulation is presented and subsequently validated. The analysis procedure is administered in two phases. In the first phase, comparison of production cost and process time in DMS and FMS is presented. The model is implemented by using an exact solution approach and results show that FMS is a viable option, compared to DMS, according to the criteria of cost, time, and productivity. In the second phase, sensitivity analysis is performed by using several FMS (n) and the impact of cells selection on the performance of system is studied. It is concluded that $n=1$ (single cell-based FMS) is more relevant for cost minimization; however, $n=6$ is a suitable candidate for producing more quantity in given time horizon (process time minimization). Lastly, key findings are reported, and future research avenues are provided.
\end{abstract}

Keywords: Dedicated Manufacturing System, Flexible Manufacturing System, Optimization, Integer Linear Programming, Sensitivity Analysis

\section{INTRODUCTION}

$\mathrm{M}$ anufacturing systems are constantly under pressure to enhance their productivity, become more profitable and reduce time wastage. The evolution of manufacturing systems due to smart technologies and industry 4.0 has enhanced the challenges for practitioners. Thus a higher level of flexibility and dynamic response is needed from the manufacturing systems [1]. The manufacturing systems can be made more flexible by grouping the production tasks, shuffling the production facilities and changing the layout [2].

The main goal of such arrangements is to enhance the efficiency of manufacturing systems and become more flexible in approaches. This will provide an enabling environment to accomplish Key Performance Indices (KPIs) in the form of cost reduction, ramp-up minimization, and improved productivity. In production systems literature, different taxonomies

${ }^{1}$ NUST Business School, National University of Science and Technology, Islamabad, Pakistan.

Email: abdulsalam_mechanical@yahoo.com (Corresponding Author)

${ }^{2}$ Department of Industrial Engineering, University of Engineering and Technology, Peshawar, Pakistan. Email: khawar@uetpeshawar.edu.pk

${ }^{3}$ Department of Mechanical Engineering Technology, University of Technology, Nowshera, Pakistan. Email: razaullah@uotnowshera.edu.pk

This is an open access article published by Mehran University of Engineering and Technology, Jamshoro under CC BY 4.0 International License. 
have been used overtime for improving the efficiency of processes.

For instance, dedicated manufacturing system (DMS) is a production taxonomy which provides high throughput of single product [3]. It is well suited for economy of scale where higher quantity of production is accomplished in limited time and reduced cost. This taxonomy is, however, not suited to contemporary production requirements which are driven by shorter life cycles, demand uncertainty, variation, and customized product requests [4]. Although DMS can provide economy of scale; however, it is not aligned with the economy of scope where more variety and flexibility are required.

In response to the dynamics of product needs, FMS is introduced to effectively address product uncertainty, demand variations, variety, and flexibility concerns. Its importance was emphasized in the research conducted in early 80's and it was noted that about $80 \%$-dollar value of metals is accomplished by producing them in small batches [5]. FMS can optimally exploit the resources designed for mass production while retaining the variety flexibility [6]. FMS can be implemented using multiple product variants and design of interdependent process [7]. This study considers efficiency comparison of dedicated and flexible systems using a two-phase approach. Firstly, comparison of DMS and FMS is performed by presenting a multi-objective model of cost and process time. The model is implemented on two case studies by using an exact solution approach. Secondly, sensitivity analysis of number of cells is carried out and its impact on performance indices is studied.

A dedicated system comprises of single/multiple specialized equipment designed to produce single part (Fig. 1). Raw material is fed into the system which is transformed to make desired products. DMS has a requirement that only one product type can be processed at a time, which is an inherent drawback in this manufacturing system. Depending upon functional differences between product types, production line might require minor adjustments (machines, tools, operators etc.), or the entire set-up is changed to match production requirements.

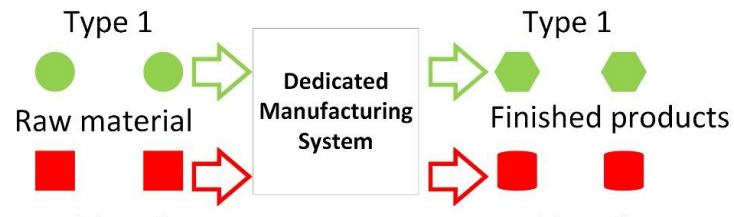

Type 2

Fig. 1: DMS designed for multiple products

FMS addressed the flexibility requirements of production planning and process operations [8]. It can be classified into cells according to product categorization, layout, and process needs. This study considers cellular FMS as shown in Fig. 2. Each FMS cell (FMC 1-4) can be regarded as a dedicated production unit that carries out designated operations repeatedly [9]. The division of FMS into cells (called flexible manufacturing cells (FMC)) is mainly driven by efficiency requirements, product demand and optimal exploitation of flexibility.

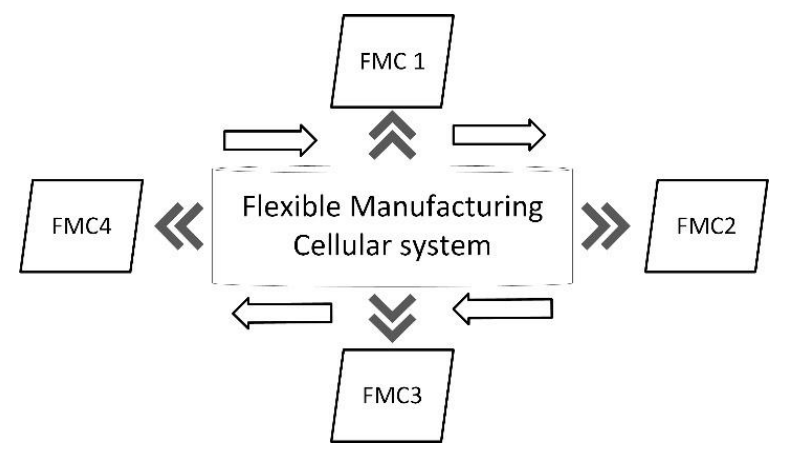

Fig. 2: Flexible Manufacturing Cellular layout for multiple product/processes

In literature, optimization of DMS and FMS systems has been performed for achieving different objectives (cost, time, and scheduling). A literature summary of relevant problems using the keywords of "DMS", "FMS" and "optimization" is provided in Table 1. Research on scheduling of DMS, change in performance by upgrading the production capacity (machines/ routes) [10-13], process cost optimization [14], modularity and interchangeability [15,16], changeover costs [17], process ramp-up time, carrying and tooling time [18-21] has been conducted. A similar pattern can be found in FMS literature where production planning and scheduling, process cost optimization and production time have been analyzed using simulation, optimization, Analytical Hierarchy 
Planning (AHP) and heuristics-based tools [22-32]. However, to the best of our knowledge, there is a dearth of literature that compares the performance of DMS and FMS. Thus, this study is an attempt towards the performance comparison of these two well research manufacturing taxonomies.

An ILP formulation is presented in this study for the purpose of comparing efficiency of DMS and FMS and its objectives are given as:

(a) To optimize the different cost components of DMS/FMS.

(b) To optimize the total time of manufacturing systems.

(c) To understand the impact of different cellular FMS (FMC) arrangements.

(d) To analyze the impact of demand overflow on the efficiency of manufacturing system.

\section{METHODOLOGY}

An Integer Linear Programming (ILP) model is presented in this section which is implemented using the following assumptions:

- The product variants are different from each other. It means that their functions as well as their production routes are somewhat different. This indicates that there will be changeover between different products.

- Each production machine works at full capacity and there is no idle time. However, different processes have different operation time which can cause some operations to wait for their predecessor operations to complete. This may result in a demand overflow at some stations. A demand overflow relaxation index $(\alpha)$ is used to compensate this aspect.

- Each product type is processed keeping in view its operational precedence.

- Two products types $\mathrm{V}_{1}$ and $\mathrm{V}_{2}$ are considered and both have the same number of operations. Depending on the nature of processes, some operations may follow similar production rule while other may differ.

- There is no setup cost as the product begins. It means that the tools are in place for processing the first operation. However, needful changes are adapted for subsequent operations.

- There is no interruption during production, and it continues up until demand (d) or production time (f) is reached. Table 2 provides the list of operations needed to manufacture each product.

The detailed schematic of considered products is provided in Appendix-I. Table 2 provides the list of operations needed to manufacture each product. The

List of operations for product1 comprises of drilling, reaming, contouring, end milling, face milling and taper turning. The production time required for each operation is also given in Table 2. Similarly, the list of operations for product 2 constitutes taper turning, drilling, pocket milling, surface finishing, boring and end milling.

Each product type needs the completion of seven operations and the concerned operational precedence are provided in Fig. 3. It is important to note that the precedence is dependent on a manufacturing system used for a product, hence, precedence for both DMS and FMS are given. It can be observed that DMS requires a strict precedence for production. It means that parallel operations are not allowed, and tool changeover occurs after a respective operation is completed. In FMS, some cases may allow parallel production whereas others may require processing a successive operation once its predecessor is completed.

\section{MATERIALS}

A multi-dimensional decision logic [33] was used in the current study. It is an exact solution approach which has been used for the analysis of relevant problems such as closed loop production systems [34, 35]. The presented model contains the important variables of cost, and time. The model details are provided below. 


\begin{tabular}{|c|c|c|c|c|c|c|c|}
\hline \multicolumn{8}{|c|}{ Table1: A review on optimization focus in DMS and FMS literatures } \\
\hline S.No. & Author (s) & & DMS & & & FMS & \\
\hline & & $\begin{array}{l}\text { Scheduling } \\
\text { \& Planning }\end{array}$ & $\begin{array}{c}\text { Cost } \\
\text { Optimization }\end{array}$ & $\begin{array}{c}\text { Process } \\
\text { Time }\end{array}$ & $\begin{array}{l}\text { Scheduling } \\
\text { \& Planning }\end{array}$ & $\begin{array}{c}\text { Cost } \\
\text { Optimization }\end{array}$ & $\begin{array}{c}\text { Process } \\
\text { Time }\end{array}$ \\
\hline 1 & $\begin{array}{c}\text { Maccarthy et al. } \\
{[10]}\end{array}$ & $\sqrt{ }$ & & & & & \\
\hline 2 & Li et al. [22] & & & $\sqrt{ }$ & & & \\
\hline 3 & Burnwal et al. [24] & & & & $\sqrt{ }$ & $\sqrt{ }$ & \\
\hline 4 & Jerald et al. [24] & & & & $\sqrt{ }$ & & \\
\hline 5 & Yao et al. [12] & $\sqrt{ }$ & & & & & \\
\hline 6 & Rauch et al. [21] & & & & $\sqrt{ }$ & & \\
\hline 7 & Lamothe et al. [16] & & $\sqrt{ }$ & & & & \\
\hline 8 & Keshner et al. [17] & & $\sqrt{ }$ & & & & \\
\hline 9 & Xin et al. [25] & & & & $\sqrt{ }$ & & \\
\hline 10 & Millgrom et al. [26] & & & & & $\sqrt{ }$ & \\
\hline 11 & Diaz et al. [27] & & & & & $\sqrt{ }$ & \\
\hline 12 & Lee et al. [31] & & & & & & $\sqrt{ }$ \\
\hline 13 & Giret et al. [32] & & & & & & $\sqrt{ }$ \\
\hline 14 & Shrouf et al. [28] & & & & & $\sqrt{ }$ & \\
\hline
\end{tabular}

\begin{tabular}{|c|c|c|c|}
\hline$\frac{\text { Table } 2}{\operatorname{Pr}}$ & perationa & $\frac{11 \text { s for }}{\text { Operat }}$ & product \\
\hline Product I & Product 2 & Product I & Product 2 \\
\hline $\begin{array}{l}\text { Drilling } \\
\text { (D) }\end{array}$ & $\begin{array}{c}\text { Taper } \\
\text { turning } \\
(\mathrm{T})\end{array}$ & 2.3 & 3.8 \\
\hline$\underset{(\mathrm{R})}{\text { Reaming }}$ & $\begin{array}{l}\text { Drilling } \\
\text { (D) }\end{array}$ & 3.4 & 2.6 \\
\hline $\begin{array}{l}\text { Contouring } \\
\text { (C) }\end{array}$ & $\begin{array}{l}\text { Pocket } \\
\text { milling } \\
\text { (P) }\end{array}$ & 4.2 & 3.5 \\
\hline $\begin{array}{l}\text { End } \\
\text { milling } \\
\text { (E) }\end{array}$ & $\begin{array}{l}\text { Surface } \\
\text { finish (S) }\end{array}$ & 3.3 & 3.0 \\
\hline $\begin{array}{c}\text { Face } \\
\text { Milling }(F)\end{array}$ & $\begin{array}{c}\text { Boring } \\
\text { (B) }\end{array}$ & 2.9 & 3.8 \\
\hline $\begin{array}{c}\text { Taper } \\
\text { turning }(\mathrm{T})\end{array}$ & $\begin{array}{l}\text { End } \\
\text { milling } \\
(\mathrm{E})\end{array}$ & 4.1 & 3.5 \\
\hline
\end{tabular}

\section{Indexes}

i Set of product types $\mathrm{i}=\{1,2, \ldots \mathrm{I}\}$

$\mathrm{p} \quad$ Set of operations in product i $\mathrm{p}=\{1,2, \ldots \mathrm{P}\}$

j Set of available machines $\mathrm{j}=\{1,2, . . \mathrm{J}\}$

$\mathrm{k} \quad$ Set of tools $\mathrm{k}=\{1,2, \ldots \mathrm{K}\}$

c Set of manufacturing cells $\mathrm{c}=\{1,2, \ldots \mathrm{C}\}$

\section{Parameters}

ot $_{\mathrm{p}}^{\mathrm{i}} \quad$ Operation time of op. $\mathrm{p}$ of product $\mathrm{i}$

$s t_{j}^{i} \quad$ Setup time of machine $j$ for product $i$

$s c_{j}^{i} \quad$ Setup cost of machine $j$ for product $i$

$o c_{p}^{i} \quad$ Operation cost of op. $p$ of product $i$

$\mathrm{tt}_{\mathrm{j}}^{\mathrm{k}, \mathrm{k} \prime}$ Tool changeover time from $\mathrm{k}$ to $\mathrm{k}^{\prime} \mathrm{b} / \mathrm{w}$ ops. on $\mathrm{m} / \mathrm{c} \mathrm{j}$

$\mathrm{tc}_{\mathrm{j}}^{\mathrm{k}, \mathrm{k} \prime}$ Tool changeover cost from $\mathrm{k}$ to $\mathrm{k}$ ' b/w ops.

on $\mathrm{m} / \mathrm{c} \mathrm{j}$

$\beta \quad$ Incremental cost of adding a new cell

$\alpha \quad$ Demand overflow relaxation index

d Demand of product $\mathrm{i}$

C Budget allocated for production

$\mathrm{f}_{\mathrm{c}} \quad$ Maximum time allowed in cell $\mathrm{c}$

$\mathrm{sc}_{\mathrm{c}} \quad$ Setup cost of cell c

$\mathrm{st}_{\mathrm{c}} \quad$ Setup time of cell c

$\delta \quad$ Index for max. capacity of a call

\section{Cost variables}

PC Production cost

MC Machine setup cost

TC Tool changeover cost

SC Cell setup cost

Time variables

PT Production time

MT Machine setup time

TT Tool changeover time

CT Cell setup time

\section{Binary variables}

$\mathrm{X}_{\mathrm{ij}} \quad 1$, if product $\mathrm{i}$ is assigned to $\mathrm{m} / \mathrm{c} \mathrm{j}$

$\mathrm{Y}_{\mathrm{jc}} \quad 1$, if $\mathrm{m} / \mathrm{c} \mathrm{j}$ is assigned to cell $\mathrm{c}$

$\mathrm{Z}_{\mathrm{p}, \mathrm{p}^{\prime}}^{\mathrm{k}, \mathrm{k}{ }^{\prime}} \quad \begin{aligned} & \text { needed } \\ & \text { ne if } \mathrm{b} / \mathrm{w} \text { operations, a tool changeover is }\end{aligned}$ 
$\begin{array}{ll}\mathrm{SM}_{\mathrm{j}}^{\mathrm{i}, \mathrm{i} \prime} & 1, \text { if } \mathrm{m} / \mathrm{c} j \text { needs setup change between } \\ \text { products } i \text { and } i\end{array}$

$\mathrm{m}_{\mathrm{ip}} \quad 1$, if op. $\mathrm{p}$ belongs to product $\mathrm{i}$
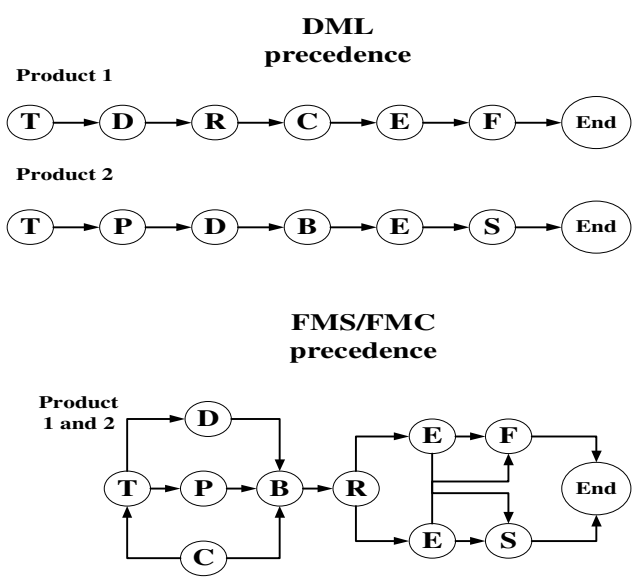

Fig. 3: Operational precedence of DMS and FMS

The mathematical model containing the multi-objective functions of total cost and total time is provided through eq. 1-23. The models are adapted to DMS and FMS with the following considerations. The time and cost of setting up machines in FMS are considered negligible. On the other hand, since DMS is not designed according to cells, its cell setup cost and cell setup time values are zero.

Equation (1) and (2) provide the total cost relationships for DMS and FMS, respectively. The relationships for different cost factors are provided through equations (3) to (6). Equation (7) and (8) offer the total time relationships for DMS and FMS respectively. The concerned relationships for respective components of time are produced through equations (9) to (12).

$$
\begin{aligned}
& \mathrm{TC}_{\mathrm{DMS}}=\mathrm{PC}+\mathrm{MC}+\mathrm{TC} \\
& \mathrm{TC}_{\mathrm{FMS}}=\mathrm{PC}+\mathrm{SC}+\mathrm{TC} \\
& \left.\mathrm{PC}=\sum_{\mathrm{p} \in \mathrm{P}} \sum_{\mathrm{j} \epsilon \mathrm{J}} \sum_{\mathrm{i} \in \mathrm{I}} \mathrm{X}_{\mathrm{ij}} \times \mathrm{m}_{\mathrm{ip}} \times O \mathrm{OC}_{\mathrm{p}}^{\mathrm{i}} \times(1-\alpha)\right) \\
& \mathrm{MC}=\sum_{\mathrm{j} \in \mathrm{J}} \sum_{\mathrm{i}, \mathrm{i \varepsilon l}} \mathrm{SM}_{\mathrm{j}}^{\mathrm{i}, \mathrm{i} \prime} \times \mathrm{sc}_{\mathrm{j}}^{\mathrm{i}} \\
& \mathrm{TC}=\sum_{\mathrm{k}, \mathrm{k} \prime \epsilon \mathrm{K}} \sum_{\mathrm{p}, \mathrm{p} \prime \epsilon \mathrm{P}} \sum_{\mathrm{j} \epsilon \mathrm{J}} \mathrm{Z}_{\mathrm{p}, \mathrm{p} \mathbf{p}^{\prime}}^{\mathrm{k}, \mathrm{k}^{\prime}} \times \mathrm{tc}_{\mathrm{j}}^{\mathrm{k}, \mathrm{k}{ }^{\prime}} \\
& \mathrm{SC}=\sum_{\mathrm{c} \in \mathrm{C}} \sum_{\mathrm{j} \in \mathrm{J}} \mathrm{Y}_{\mathrm{jc}} \times \mathrm{sc}_{\mathrm{c}} \times(1-\delta)(1+\beta) \\
& \mathrm{TT}_{\mathrm{DMS}}=\mathrm{PT}+\mathrm{MT}+\mathrm{TT} \\
& \mathrm{TT}_{\mathrm{FMS}}=\mathrm{PT}+\mathrm{CT}+\mathrm{TT} \\
& \mathrm{RT}=\sum_{\mathrm{p} \in \mathrm{P}} \sum_{\mathrm{j} \varepsilon J} \sum_{\mathrm{i} \epsilon \mathrm{I}} \mathrm{X}_{\mathrm{ij}} \times \mathrm{m}_{\mathrm{ip}} \times \mathrm{ot}_{\mathrm{p}}^{\mathrm{i}} \times(1-\alpha) \\
& \mathrm{MT}=\sum_{\mathrm{j} \in \mathrm{J}} \sum_{\mathrm{i}, \mathrm{i}, \epsilon \mathrm{I}} \mathrm{SM}_{\mathrm{j}}^{\mathrm{i}, \mathrm{i} \prime} \times \mathrm{st}_{\mathrm{j}}^{\mathrm{i}}
\end{aligned}
$$

$$
\begin{aligned}
& \mathrm{TT}=\sum_{\mathrm{k}, \mathrm{k} \prime} \in \mathrm{K} \sum_{\mathrm{p}, \mathrm{p}, \varepsilon \mathrm{P}} \sum_{\mathrm{j} \in \mathrm{J}} \mathrm{z}_{\mathrm{p}, \mathrm{p}^{\prime}}^{\mathrm{k}, \mathrm{k}^{\prime}} \times \mathrm{tt}_{\mathrm{j}}^{\mathrm{k}, \mathrm{k}^{\prime}} \\
& \mathrm{CT}=\sum_{\mathrm{c} \in \mathrm{C}} \sum_{\mathrm{j} \in \mathrm{J}} \mathrm{Y}_{\mathrm{jc}} \times \mathrm{st}_{\mathrm{c}} \times(1-\delta) \\
& \sum_{\mathrm{c} \in \mathrm{C}} \mathrm{Y}_{\mathrm{jc}}=1 \quad \forall j=[1,2, \cdots, \mathrm{J}] \\
& \sum_{\mathrm{i}, \mathrm{i \in I}} \mathrm{SM}_{\mathrm{j}}^{\mathrm{i}, \mathrm{i} \prime}=\leq 1 \forall \mathrm{j}=\{1,2, \cdots, \mathrm{J}\} \\
& \mathrm{PC}+\mathrm{MC}+\mathrm{TC}+\mathrm{SC} \leq \mathrm{C} \\
& \mathrm{CT}+\mathrm{PT}+\mathrm{TT} \leq \mathrm{f}_{\mathrm{c}} \\
& \mathrm{PC}, \mathrm{MC}, \mathrm{TC}, \mathrm{SC} \geq 0 \\
& \text { PT, MT, TT, CT } \geq 0 \\
& X_{\mathrm{ij}} \quad \in\{0,1\} \quad \forall \mathrm{i} \in \mathrm{I}, \forall \mathrm{j} \in \mathrm{J} \\
& \mathrm{Y}_{j c} \quad \in\{0,1\} \quad \forall \mathrm{j} \in \mathrm{J}, \forall \mathrm{c} \in \mathrm{CJ} \\
& \mathrm{Z}_{\mathrm{p}, \mathrm{p} \prime}^{\mathrm{k}, \mathrm{k} \prime} \quad \in\{0,1\} \quad \forall \mathrm{p} \in \mathrm{P}, \forall \mathrm{k} \in \mathrm{K} \\
& \mathrm{SM}_{\mathrm{j}}^{\mathrm{i}, \mathrm{i} \prime} \in\{0,1\} \quad \forall \mathrm{i} \in \mathrm{I}, \forall \mathrm{j} \in \mathrm{J} \\
& m_{i p} \quad \in\{0,1\} \quad \forall \mathrm{i} \in \mathrm{I}, \forall \mathrm{p} \in \mathrm{P}
\end{aligned}
$$

The set of constraints are provided through equations (13)-(23). Constraints 13 and 14 ensure that each machine is assigned to exactly one cell (in the case of FMS) and there is at most one machine setup change between consecutive products (in the case of DMS), respectively. Constraints 15 and 16 impose the budget and allowed time constraints, respectively. The domain constraints of non-negativity and linear variables are provided through equations (17)-(18) and (19)-(23), respectively. An overflow relaxation measure is used for reducing the queue length of product line-up.

It is important to note that few relationships exhibit a non-linear relationship (eq. 3 and 9). These relationships were linearized by using linear approximation technique. It is an important step that enables the exact solution approaches to solve the considered problems. The model was implemented in LINGO 17.0 using Core i5 CPU, 64 Bit windows 10 with processing capability of $2.50 \mathrm{GHZ}$.

\section{RESULTS}

The Model was separately solved for DMS and FMS systems. For an easy illustration, and without the loss of generality, a comparison between both systems is offered in this section. Fig. 4 provides the results of cost solutions of DMS and FMS for both products. Since FMS is designed in cells, hence, FMS and flexible manufacturing cells (FMC) can be considered interchangeable terms in this study. Similarly, DMS 
and dedicated manufacturing lines (DML) are also interchangeable terms.

The cost breakdown is provided according to different operations. It can be observed that different operations result in different values of costs. Further, FMC is a more viable solution as it has lower values of costs due to multiple reasons. FMS/FMC does not require machine setup between different operations which reduces the overall cost value. Similarly, since FMC allows multiple operations in parallel, hence, there is little waiting in between the processes. Thus, a demand overflow relaxation is no needed. FMC system help achieving the cost efficiency of almost 13\% in producing each product.
A similar comparison can be drawn from the analysis of time and respective results are provided in Fig. 5. It can be observed that FMC is a relative improved option as it takes less time in completing the production. In fact, it is time efficient for all operations of each product. Statistics show that FMC is effective in completing all operations in $7 \%$ and $9 \%$ less time, compared to DMC/DML, for product 1 and 2, respectively. The reasons behind time efficiency of FMC are threefold. Firstly, its setup time in minimal, as machine setup is not required in the case of FMC/FMS. Secondly, FMC spindle/turret can hold multiple tools which reduces the tool changeover time. Thirdly, FMC can accommodate parallel operations while respecting the precedence constraints, which helps in reducing the overall time.

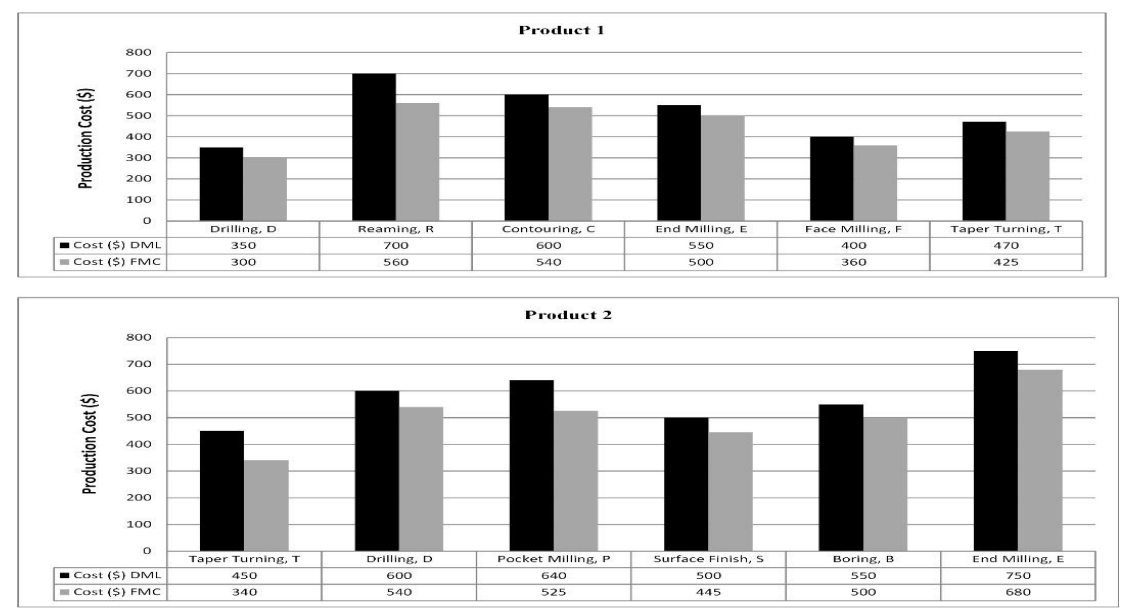

Fig. 4: Comparison of cost indices between DMS and FMS
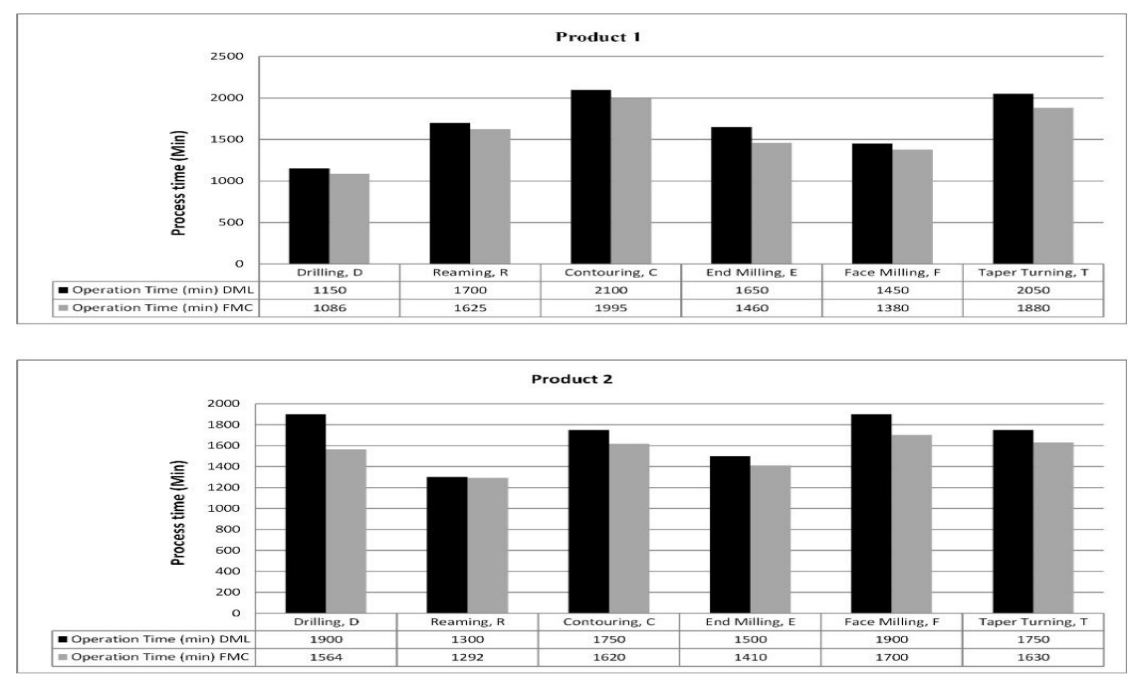

Fig. 5: Process Time Comparison Between DMS and FMS for Product 1 and 2 
In the next phase of the study, a sensitivity analysis of different variables was performed by changing the number of available cells. The number of cells were increased/decreased by enhancing/reducing the maximum capacity of each cell. The respective results of number of cells, incremental cost of extra cell, productivity (production quantity) and total cost values are provided in Fig. 6. It can be observed that, as the number of cells increase, corresponding values of incremental cost, productivity and total cost increases as well. Thus, a manager may decide whether to produce more or to control the total cost solution. Further, higher number of cells will need more space. A combined analysis of production quantity, cost and occupied space is needful on the part of production manager. As an illustration, Fig. 7 provides a single, two and three cells-based arrangement of FMCs. Each arrangement groups together certain operations in a cell so that desired objectives can be met. As discussed earlier, three-cells arrangement will offer more production quantity with higher cost and will require a large space for manufacturing.

A demand overflow relaxation was used to accommodate the queue length. Fig. 8 provides the results of sensitivity analysis of relaxation index and its impact on productivity (quantity of products delivered by a manufacturing system). The horizontal axis contains various levels of demand overflow relaxation index while the right and left vertical axes represent demand length/queue length and productivity, respectively. It can be observed that as the relaxation index value increases, the queue length decreases whereas the quantity of production increases. In other words, a higher quantity of products can be manufactured when the waiting time is less. These

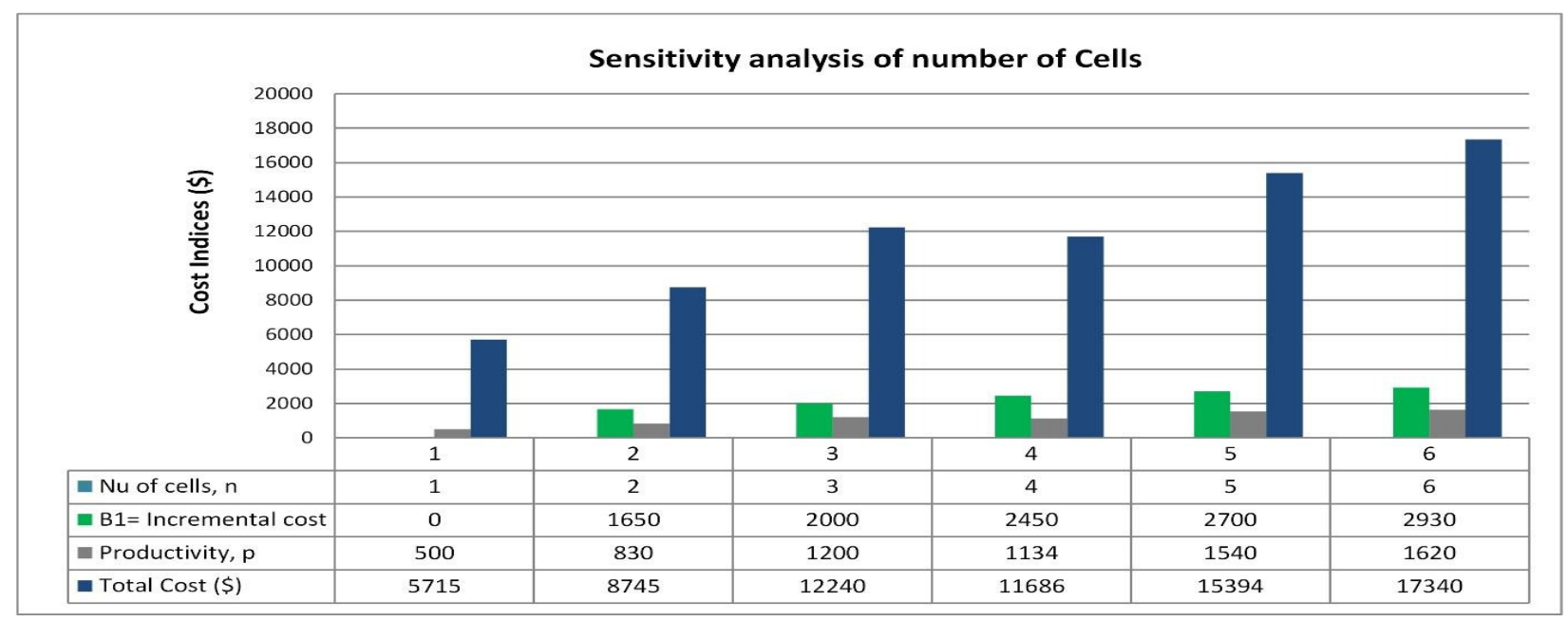

Fig. 6: Sensitivity Analysis for number of FMS Cells

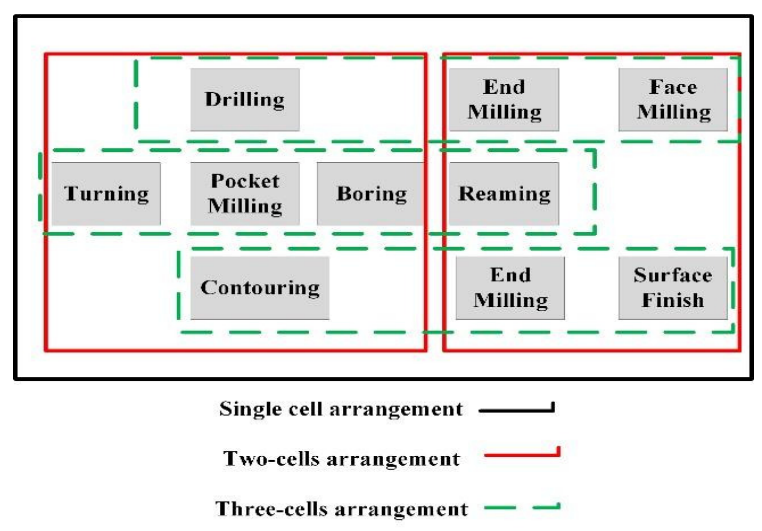

.Fig. 7: Multiple cellular arrangements of FMCs

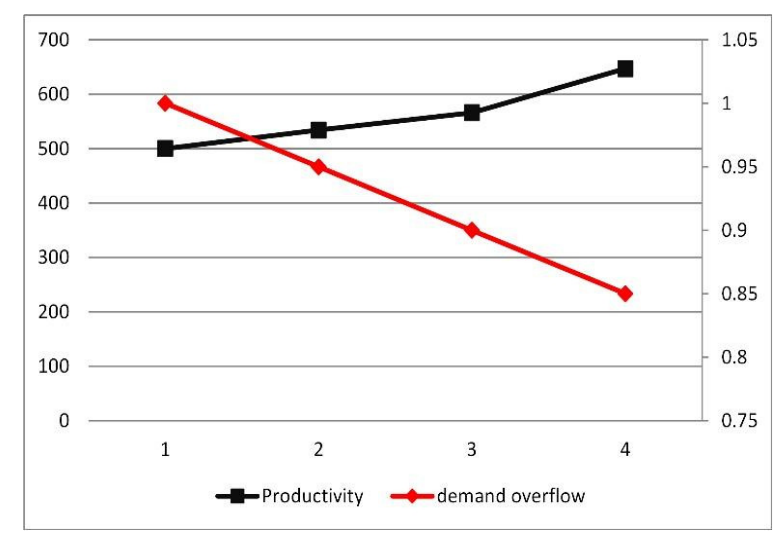

Fig. 8: Product Overflow Rel 
findings further highlight the advantages of FMC as it allows parallel operations which helps in reducing the queue length. Thus, it can be concluded that FMC is a better solution, compared to DMC, against the criteria of cost, time, and productivity.

\section{CONCLUSION}

Modern manufacturing systems are faced with multiple challenges that require it to be more agile and flexible in its approaches. Thus, it is imperative to design such systems around the aspects of cost-efficiency, product variety and high throughput. This study presented a comparison between DMS/DML and FMS/FMC and proposed a multi-objective model of cost and time. The model was implemented using an exact solution approach by using two case studies. The results suggested that FMC is a viable option as it resulted in least total cost, least total time, and high productivity. These results will assist the decision makers in selecting an appropriate production systemwhen facing the challenges of cost, time, productivity and utilizing the available space.

The presented model was deterministic which was implemented by using an exact solution approach. Future research can add stochastic aspects of demand uncertainty, and product arrival to make the model more realistic. Further, non-exact and evolutionary approaches can be used for solving complex case studies. Such approaches can solve higher-order complex problems in a considerable time. Lastly, a new manufacturing system, called reconfigurable manufacturing system, can be modeled and compared to the existing manufacturing taxonomies. This will enhance the applicability of findings to a wider range of manufacturing systems.

\section{ACKNOWLEDGEMENT}

The authors are thankful to the feedback of anonymous reviewers which helped in substantially improving the contents of this manuscript.

\section{REFERENCES}

[1] Yadav A., Jayswal S. C., "Modelling of flexible manufacturing system: a review". International Journal of Production Research, Vol. 56, No.7, pp. 2464-2487, 2018.

[2] Maganha I., Silva C., Ferreira L. M. D., "Understanding reconfigurability of manufacturing systems: An empirical analysis", Journal of Manufacturing Systems, Vol. 48, pp. 120-130, 2018.

[3] Kiran K., Kayacan M. C., "Cutting force modeling and accurate measurement in milling of flexible workpieces", Mechanical Systems and Signal Processing, Vol. 133, 2019.

[4] Marsillac E., Roh, J. J., “Connecting product design, process and supply chain decisions to strengthen global supply chain capabilities". International Journal of Production Economics, Vol. 147, pp. 317-329, 2014.

[5] Dixit S., Raj T., "Identification and modelling of the various factors affecting the productivity of FMS", International Journal of Productivity and Quality Management, Vol. 17, No. 3, pp. 353-379, 2016.

[6] Tao F., Cheng Y., Zhang L., Nee, A. Y., "Advanced manufacturing systems: socialization characteristics and trends", Journal of Intelligent Manufacturing, Vol. 28, No.5, pp. 1079-1094, 2017.

[7] Reveliotis S. A., Lawley M. A., Ferreira, P. M., "Structural control of large-scale flexibly automated manufacturing systems", Computer Aided and Integrated Manufacturing Systems: Techniques and Applications, 2019.

[8] Lechuga G. P., Sánchez F. M. "Modeling and optimization of flexible manufacturing systems: A stochastic approach", Proceedings of the International Conference on Intelligent Computing and Optimization, Springer, Cham. pp. 539-546, 2018.

[9] Laurenza E., Quintano M., Schiavone F., Vrontis D., "The effect of digital technologies adoption in healthcare industry: a case based analysis. Business Process Management Journal, Vol. 24, No. 5, pp. 1124-1144, 2018. 
[10] Maccarthy B. L., Liu J., "Addressing the gap in scheduling research: a review of optimization and heuristic methods in production scheduling". The International Journal of Production Research, Vol. 31, No.1, pp. 59-79. 1993.

[11] Zhang Q., Grossmann I. E., "Planning and scheduling for industrial demand side management: advances and challenges", Alternative Energy Sources and Technologies, Springer, Cham, pp. 383-414, 2016.

[12] Yao J., Liu L., "Optimization analysis of supply chain scheduling in mass customization", International Journal of Production Economics, Vol. 117, No.1, pp. 197-211. 2009.

[13] Nguyen S., Mei Y., Zhang M., "Genetic programming for production scheduling: a survey with a unified framework", Complex and Intelligent Systems, Vol. 3, No. 1, pp. 4166, 2017.

[14] Hankammer S., Steiner F., "Leveraging the sustainability potential of mass customization through product service systems in the consumer electronics industry", Procedia CIRP, Vol. 30, pp. 504-509, 2015.

[15] Centobelli P., Cerchione R., Murino T., \& Gallo, M., "Layout and material flow optimization in digital factory", International journal of Simulation Modelling, Vol. 15, No. 2, pp. 223-235, 2016.

[16] Lamothe, J., Hadj-Hamou, K., \& Aldanondo, M., "An optimization model for selecting a product family and designing its supply chain", European Journal of Operational Research. Vol. 169, No.3, pp. 1030-1047. 2006.

[17] Keshner, M. S., \& Arya, R., "Study of Potential Cost Reductions Resulting from Super-LargeScale Manufacturing of PV Modules", Final Subcontract Report, 7 August 2003. 2004

[18] Li J., González M., Zhu Y., “A hybrid simulation optimization method for production planning of dedicated remanufacturing", International
Journal of Production Economics, Vol. 117, No2, pp. 286-301. 2009.

[19] Dubey R., Gunasekaran, A., "Agile manufacturing: framework and its empirical validation", The International Journal of Advanced Manufacturing Technology, Vol. 76, No. 9, pp. 2147-2157, 2015.

[20] Lai T. C., Sotskov Y. N., Egorova N. G., Werner F., "The optimality box in uncertain data for minimising the sum of the weighted job completion times", International Journal of Production Research, Vol. 56, No. 19, pp. 63366362, 2018.

[21] Rauch, M., Hascoet, J. Y., Hamann, J. C., Plenel, Y., "Tool path programming optimization for incremental sheet forming applications", Computer-Aided Design, Vol. 41, No.12, pp. 877-885. 2009.

[22] Burnwal S., Deb S., "Scheduling optimization of flexible manufacturing system using cuckoo search-based approach", The International Journal of Advanced Manufacturing Technology, Vol. 64, pp. 951-959. 2013.

[23] Zhang S., Wong T. N., "Integrated process planning and scheduling: an enhanced ant colony optimization heuristic with parameter tuning", Journal of Intelligent Manufacturing, Vol. 29, No. 3, pp. 585-601, 2018.

[24] Jerald J., Asokan P., Prabaharan G., Saravanan, R., "Scheduling optimization of flexible manufacturing systems using particle swarm optimization algorithm", The International Journal of Advanced Manufacturing Technology, Vol. 25, No.9-10, pp. 964-971. 2005.

[25] Xia W., Wu Z., "An effective hybrid optimization approach for multi-objective flexible job-shop scheduling problems", Computers \& Industrial Engineering, Vol. 48. No. 2, pp. 409-425. 2005.

[26] Milgrom P., Roberts J., "The economics of modern manufacturing: Technology, strategy, and organization", The American Economic Review, pp. 511-528. 1990. 
[27] Diaz N., Dornfeld D., "Cost and energy consumption optimization of product manufacture in a flexible manufacturing system", Leveraging Technology for a Sustainable World. pp. 411-416. 2012.

[28] Shrouf F., Ordieres-Meré J., García-Sánchez A., \& Ortega-Mier, M., "Optimizing the production scheduling of a single machine to minimize total energy consumption costs", Journal of Cleaner Production, Vol. 67, pp. 197-207. 2014.

[29] Singh R., Khan, B., "Meta-hierarchicalheuristic-mathematical-model of loading problems in flexible manufacturing system for development of an intelligent approach", International Journal of Industrial Engineering Computations, Vol. 7, No. 2, pp. 177-190, 2016.

[30] Kim T., Glock C. H., "Production planning for a two-stage production system with multiple parallel machines and variable production rates", International Journal of Production Economics, Vol. 196, pp. 284-292, 2018.

[31] Lee S. L., O'Connor T. F., Yang X., Cruz C. N., Chatterjee, S., Madurawe, R. D., \& Woodcock, J., "Modernizing pharmaceutical manufacturing: from batch to continuous production", Journal of Pharmaceutical Innovation, Vol. 10, No.3, pp. 191-199. 2015.

[32] Giret A., Trentesaux D., Prabhu V., "Sustainability in manufacturing operations scheduling: A state of the art review", Journal of Manufacturing Systems, Vol. 37, pp. 126-140. 2015.

[33] Sivrikaya B. T., Kaya A., Dursun M., Çebi F., "Fuzzy AHP-goal programming approach for a supplier selection problem", Research in Logistics and Production, Vol. 5, No. 3, pp. 271285. 2015.

[34] Khan A. S., "Analysis of Closed Loop Production System Using Orthogonal Array and Integer Programming Optimization", Mehran University Research Journal of Engineering and Technology, Vol. 38, No. 3, pp. 851-866, 2019.

[35] Abro K. A., Shaikh A. A., Dehraj S., "Exact solutions on the oscillating plate of Maxwell fluids", Mehran University Research Journal of Engineering and Technology, Vol. 35, No. 1, pp. $155,2016$.

\section{APPENDIX-I}
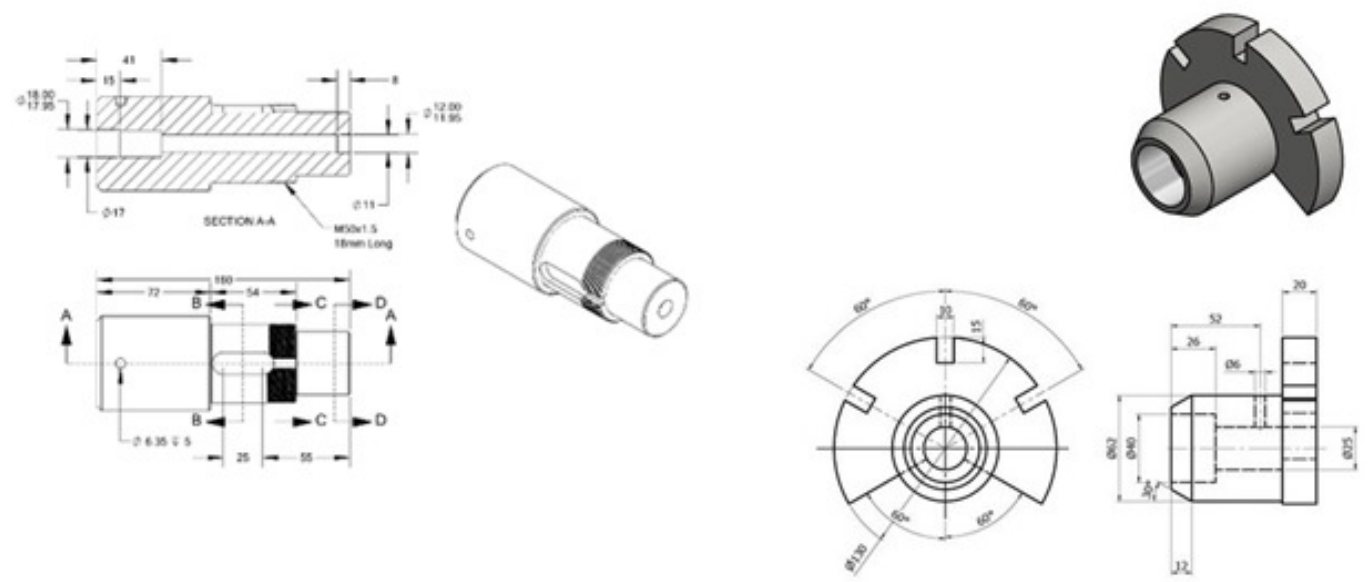

Appendix-I: Schematic of Product 1 (left) and Product 2 (right) 